hydration caves, because of the fact that, as previously shown, the process of hydration has been such an important factor in their formation.

Edward H. Kraus.

Mineralogical Laboratory, UNIVERSITY OF MICHIGAN.

\section{A PRELIMINARY NOTE ON CLOVER DISEASES IN} TENNESSEE.

For a few years past there has been considerable complaint among Tennessee farmers of the failure of the red clover crop. A careful investigation of the question was begun by the botanical department of the Tennessee Experiment Station early in the present season, and a short account of the present stage of these investigations may be of some interest.

While the whole state has been more or less explored with reference to diseases affecting clover, the immediate region about Knoxville has been more carefully studied, and may be assumed as typical of the situation throughout Tennessee, and perhaps adjoining states.

The crop begins to die in the summer following late winter sowing. The trouble has been popularly attributed to some supposed condition of the soil, and so termed 'clover sickness' of the land. It was soon learned, however, that the malady is independent of soil conditions, and there was at the outset a strong presumption in favor of some fungous or bacterial disease. Our later investigations have fully justified this opinion..

Early in the season a few leaves were found to be attacked by the clover rust, Uromyces trifolii (Hedw.) Lev. This disease occurs so sparingly that it may be left out of consideration. Careful search frequently reveals the presence of Pseudopeziza trifolii (Bernh.) Fuck. While this fungus caused considerable damage in some instances, it may also be left out of account.

A rather destructive disease, apparently caused by Macrosporium sarcinceforme Cav., ${ }^{1}$ is very frequent and widely disseminated. It

${ }^{1}$ Cited in Tubeuf and Smith, 'Diseases of Plants,' 1896, p. 517; also Malkoff, Zeits. $f$. Pflanzenkr., Bd. XII., pp. 283-285. often appears on stray alsike plants (Trifolium hybridum L.) associated with the red clover, which is not true of any other parasites discussed in this paper. The Macrosporium disease appears capable of destroying the clover plant unassisted by any'other parasite, though this statement is based only on inspection in the field.

The most destructive disease thus far found is what appears to be an undescribed species of Colletotrichum. In its general appearance this disease very closely simulates the anthracnose of clover (Stengelbrenner), described by Mehner $^{2}$ and Kirchner ${ }^{3}$ and by the latter attributed to the attacks of Gloosporium caulivorum n. sp.

The Colletotrichum species here referred to causes considerable injury to young clover plants in early summer, where it confines its attacks to the petioles of the leaves. Its greatest damage, however, is done to blooming and fruiting plants, where it attacks the stems most often just below the flower heads, but frequently at other points, causing the sudden blackening and death of a limited region, eventually destroying the entire plant.

A description and characterization of this species will shortly appear, and further experiments now under way will be described in a forthcoming bulletin of the Tennessee Experiment Station. Samuel M. Bain,

UnIVERSity of Tennessee, Samuel H. Essary.

Knoxville, Tenn.

A NEW ARMORED DINOSAUR FROM THE UPPER CRETACEOUS OF WYOMING.

THE writer has recently been fortunate in the discovery, near Lander, Wyoming, of the larger part of a skeleton of a remarkable dinosaur, evidently new. The animal is about half the size of Stegosaurus, to which it is allied, but is peculiar in having a heavy bony carapace, two inches or more in thickness. This carapace is covered with, and for the most part firmly united to, a mosaic of pentagonal dermal bony plates, much like those of Glyptodion. Each plate is about four inches

${ }^{2}$ Zeits. f. Pflanzenkr., Bd. XI., p. 193, 1901.

${ }^{3}$ Ibid., Bd. XII., p. 10. 